\title{
Service Quality and Donor Trust and Its Impact on Donor Loyalty (Survey at LAZ Synergy Foundation)
}

\author{
Eko Ruslamsyah ${ }^{1}$, Agus Rahayu $^{2} \&$ Rida Rosida ${ }^{3}$. \\ Indonesia University of Education \\ E-mail: ekoruslamsyah@student.upi.edu, agusrahayu@upi.edu, rida.rosida@upi.edu
}

\begin{abstract}
Islamic economics regulates development through instruments of Islamic development funds, including zakat, infaq, and alms. But the collection of ZIS funds is still low compared to its potential. This research is designed to analyze the influence of service quality, donor's trust in donor's loyalty. The population of this study was donors at the Sinergi Foundation institution. The sampling technique used was purposive sampling quota sampling with a total sample of 100 people. In addition, it also uses path analysis to determine the relationship of influence between these variables. The results of this study indicate that, first, service quality has a positive and significant effect on donor's trust. Second, service quality does not have a positive and significant effect on donor's loyalty. Third, donor trust has a positive and significant effect on donor loyalty. Fourth, service quality affects the loyalty of donors through trust in donors as an intervening variable.
\end{abstract}

Keywords. Service Quality, Donor Trust, Donor Loyalty

\section{INTRODUCTION}

Islamic economics regulates development through instruments of Islamic development funds, including zakat, infaq, and alms. Zakat and infaq in Indonesia have a vast optimization opportunity because the majority population in this country is Muslim. According to the data from Badan Pusat Statistik (cited in Kementrian Agama Republik Indonesia, 2013), the Muslim population in Indonesia is around 207.176 .162 people or about $87,21 \%$ of the total population in Indonesia, and then from that number, 41.763 .592 or about 20,16\% of the total Muslim population in Indonesia are in West Java. This means that the most significant majority of the Indonesian Muslim population living in West Java.

Firdaus \& Beik (2012) mentions that the potential national charity in 2011 reached 3.4 percent of total GDP, or in other words, zakat potential in Indonesia estimated to reach Rp 217 trillion. In fact, according to BAZNAS, the potential for a national charity in 2015 reached Rp 286 trillion. However, the enormous potential that is inversely proportional to the realization of zakat, donation, and charity in Indonesia is the only country that reached 3.7 trillions.

Some fundamental problems cause an imbalance between the potential zakat funds raised, including 1). Regulation that the government has made through Law No. 38 in 1999 has not felt perfect because it merely regulates how to manage zakat, but has not touched the issue more essential is how to collect zakat from muzakki, as well as the sanction given to, were reluctant to fulfill their zakat. 2). Amil zakat institutions and agencies that have been there having not provided exemplary service to the community. So that it adversely affects the confidence (trust) communities (Yusrizal, ghafur, \& Sabri, 2017).

Consumer confidence in the product and the company's credibility is one factor that can make consumers loyal to the company. Kertajaya confirmed this in Elrado (2014) that customer trust is an asset to achieve customer loyalty.

Some previous empirical research examines the service of which by Elrado, et al. (2014) which indicates that the variable quality of service consists of five indicators of physical evidence (tangible), reliability, responsiveness, assurance, and empathy effect on customer confidence. Meanwhile, previous studies related to trust the loyalty as investigated by Eldorado, et al., also investigated by Sugiyati (2013), explain that belief positive and significant effect on loyalty. The emergence of zakat and development organizations is getting better from year to year 
, leading to a competitive challenge in finding and retaining donors. One private zakat management organization in Indonesia is the Foundation for the People or Semai Synergy Foundation.

Over time, the Synergy Foundation has also experienced a wide range of issues associated with donor loyalty. The number of donors who had dealings with the Synergy Foundation has increased from year to year. But an increasing number of donors who donate once is not proportional to the number of active donors who donate at the agency. Donors who are still active in synergy occurs volatile, and last in 2017, active donors donate only about 4.339 people while all the donors never donate as many as 24.237 people. It can thus be understood that the loyalty of donors to the Synergy Foundation is still unstable. So this is the question on the confidence of donors and the quality of service at LAZ Synergy Foundation.

Based on the explanation above, the writer is interested in researching the service quality of Amil Zakat Institution in Synergy Foundation and donors trust and their impact on its loyalty of donors to the LAZ. Therefore, the research title is "Quality of Service and Trust and Loyalty Effect on Donators (Survey on LAZ Synergy Foundation)."

Based on the background of the research problem and the symptoms identified above, it can be formulated the problem of this research into the formulation of the problem as follows:

How would you describe the quality of service, trust, and donors' loyalty to LAZ Synergy Foundation?

1. Whether there is an influence on the quality of service LAZ Muzaki confidence?

2. Whether there is an influence of service quality on loyalty donors to LAZ Synergy Foundation?

3. Are there beliefs that influence Muzakki loyalty to LAZ Synergy Foundation donors?

4. Does service quality influence on loyalty of LAZ LAZ donors to the Synergy Foundation with confidence muzakki as an intervening variable?

The general objective of this study is to describe and influence the quality of services, trust, and loyalty of donors in paying zakat, donation, and shodaqoh in LAZ Synergy Foundation.

The hypothesis proposed for this study are as follows:

1. There is a positive effect of service quality on donor confidence.

2. There is a positive influence on the quality of services to the loyalty of donors to LAZ.

3. There is a positive influence on loyalty donor trust donors to LAZ.

4. There is a positive influence on the quality of services to loyalty to LAZ donors with donor confidence as an intervening variable.

\section{LITERATURE REVIEW THEORETICAL FOUNDATION}

\section{a. Quality of Service}

According to Kotler in Maisur, et al. (2015), quality of service is any activity or benefit that may be given by one party to another that is essentially intangible and does not also result in the ownership of something. Production may or may not be associated with a physical product. LAZ service is one of the things that appeal muzakki in depositing zakat (Sutomo, Najib, \& Djohar, 2017).

Quality of service measures how good a given level of service that can suit customer expectation (Wijaya, 2011). Quality of service is defined as any action or activities offered by one party to the other party in the form of quality or excellence level expected by consumers to satisfy their wants and needs (Yazid A. t., 2017).

Islam teaches that if you want to provide good operating results in the form of goods and services should provide quality, do not give the bad or not qualified to others (Saktiandy, 2013). Indicators of service quality by Parasuraman in Ciptono (2011) identifies five dimensions of quality in services, namely:

1. Tangibles, including physical facilities, equipment, personnel, and means of communication.

2. Reliability, the ability to produce the promised service performance accurately and indeed. This means that the service must be on time and in the exact specification, without error, whenever the services are rendered.

3. responsiveness, that can address the needs or can be defined by a willingness to help customers and provide prompt service 
4. Assurance includes knowledge of and respect for employees and their capability, which means the assurance services provided.

5. Empathy that is the inspiration and the personal attention of the consumer.

In addition to the five indicators, there are indicators of service quality in Islam by (Saktiandy, 2013) namely Shariah Compliance. Then the service quality indicators should be linked with the marketing mix, namely 3P them are People, Process and Physical Evidence (Alma, 2008).

\section{b. Donor Trust}

According to Hasrina, et al (2018), trust in muzakki or donor is muzakki willingness to rely on charity or Baitul Mal institutions to distribute their zakat to mustahiq muzakki sure the agency is professional, trustworthy, and transparent. While trust by Usria (2014) consumer / muzakki is all the knowledge possessed by the consumer / muzakki and all the conclusions made by the consumer / muzakki about objects, attributes, and benefits. Objects can be products, people, companies, and everything with beliefs and attitudes. Attributes are characteristics or features that may be owned or not owned by the object.

Confidence indicators, according to Robbins and Judge in Umar (2014) says there are four key dimensions in the concept of trust, namely integrity, referring to the honesty and truthfulness, competence, associated with the knowledge and skills of technical and interpersonal skills of the individual, consistency, associated with the reliability, the ability to predict and individual votes sniper in handling the situation and transparency (openness). Meanwhile, according to Mayer et al in Jasfar (2012) stated that the confidence indicator consists of three components, namely:

a) Integrity is a consumer perception that the company follows principles accepted as fulfilling promises to behave ethically and honestly.

b) Goodness (benevolence), which is based on the size of the discount trust partnership goals and motivation, are the advantages for other organizations when new conditions arise, in which the commitment is not formed.

c) Competence, competence is the ability to solve problems faced by consumers and meet their every need.

Rizal Djalil in Nasim (2014) examines the Amil Zakat institutions explicitly; trust muzakki can be formed with credibility, competence, and moral attitudes.

\section{c. Donor Loyalty}

Lovelock and Wright in Jasfar (2012) explain that customer loyalty is the willingness of customers to continue to subscribe to a company in the long term, purchase and use the services repeatedly and willingly recommend the company's services to others.

According to Pearson in Wantara (2015), loyalty is an attitude or behavior of a consumer who benefits the company, such as the repurchase of the company's products or services and recommends products and services to others. According to Saktiandy (2013), consumer loyalty donor loyalty mean, if inferred from the definition above, is a deep commitment to repurchase or subscribe to a product or service consistently in the future.

Loyalty in Islam is called al-wala '. Etymologically, al-wala 'has several meanings: love, help, follow and draw close to something (Salma, 2015). Customer loyalty in Islam occurs when the muamalah activity can benefit both parties to fulfill the obligations and rights of each through the implementation of Islamic values (Zulfa, 2010).

Indicators of customer loyalty, according to Kotler and Keller (2009), is repeat purchase (loyalty towards the purchase of the product), retention (resistance to impact negatively on the company), referrals (refer in total existence company).

\section{PREVIOUS RESEARCH}


Gunawan (2017) explains that the applicant of zakat institutions will be more loyal with excellent service. These results are supported by Lusiati (2010) that states there is a significant favorable influence on the service quality of muzakki satisfaction, and there is a significant positive effect on muzakki satisfaction with muzakki loyalty. Yazid (2017) also explains in his research that service quality had a positive and significant influence on interest in muzakki.

However, according to the research results by Nuraini dan Ridho (2015), which shows that partially, service quality does not influence the interest of muzakki to distribute zakat. Darwin dan Kunto (2014) dan Qomariah (2012) also reveals that service quality did not affect consumer loyalty, so other variables are needed to create consumer loyalty. The research on service quality towards loyalty to LAZ still has little to do with trust but takes more concern to muzakki satisfaction.

\section{RESEARCH METHODOLOGY}

This study uses causality with a quantitative approach. In addition, the research design used is explanatory research design which is a research design that highlights the relationships between variables by first using a framework of thought, then formulated in the form of a hypothesis.

The population in this study was all donors. Synergy Foundation is still actively donating to 2017 as many as 4.339 people. The sampling technique used donor is a non-probability sampling in which every member of the population does not have the opportunity or the same opportunities as a sample. The technique is taken for the Synergy Foundation donor population spread very widely. The type of sampling is purposive sampling with a quota sampling approach. Characteristics of this type of sampling are that the sampled based on the needs of research or sample taken with the intent and purpose of specific information for researchers.

While the respondents required criteria are as follows:

1. Donors who donate at institutions Synergy Foundation

2. Donors who donate more than twice

3. Donors who live in the city of Bandung, Bandung regency, West Bandung regency, and Cimahi.

To meet the needs of this research, the researchers needed a sample of 100 people for using path analysis method using minimal regression study population that is 30 (Ghozali, 2006). In addition to the above criteria are also based on a limited number of researchers in terms of time, cost, location, and other things.

In analyzing this study, its data using path analysis (path analysis) using SPSS analytical tool 22. Following the opinion of Ridwan and Kuncoro (2012) that path analysis is used to "analyze the pattern of the relationship between variables in order to determine the effect of the direct and indirect effects of a set of independent variables (exogenous) to the dependent variable (endogenous)."

\section{DISCUSSION}

\section{a. General Characteristics of Respondents}

The respondent's general characteristics of respondents will portray the results of the research and explain the facts that occurred in the field concerning gender, recent education, and employment.

Table 5 Characteristics of Respondents by Gender

\begin{tabular}{clrr} 
No. & Gender & $\begin{array}{c}\text { Frequency / } \\
\text { People }\end{array}$ & Percentage \\
\hline 1 & Man & 27 & $27 \%$ \\
2 & woman & 73 & $73 \%$ \\
\hline \multicolumn{2}{c}{ Total number } & $\mathbf{1 0 0}$ & $\mathbf{1 0 0 \%}$ \\
\hline
\end{tabular}

Source: Respondents answer Score Results of Treatment

The results of Table 5 show that the characteristics of respondents by sex are more female respondents than males.

Table 6 Characteristics of Respondents by Age 


\begin{tabular}{ccrr}
\hline No. & Age & $\begin{array}{c}\text { Frequency } \\
\text { People }\end{array}$ & Percentage \\
\hline 1 & $20-29$ & 7 & $7 \%$ \\
2 & $30-39$ & 26 & $27 \%$ \\
3 & $40-49$ & 30 & $30 \%$ \\
4 & $50-59$ & 23 & $23 \%$ \\
5 & $60-69$ & 10 & $10 \%$ \\
6 & $70-79$ & 3 & $3 \%$ \\
7 & $80-89$ & 1 & $1 \%$ \\
\hline \multicolumn{2}{c}{ Total } & $\mathbf{1 0 0}$ & $\mathbf{1 0 0 \%}$ \\
\hline
\end{tabular}

Based on Table 6, the donor's age who actively donates exists in the age range 20 to 39 years by $34 \%$. At the same time, the donors were in the age range 36 to 40 years at $66 \%$.

Table 7

Characteristics of Respondents Based on Latest Education

\begin{tabular}{ccrr}
\hline No. & Last education & Total & \multicolumn{2}{c}{ Percentage } \\
\hline 1 & No school & 0 & $0 \%$ \\
2 & SD & 0 & $0 \%$ \\
3 & SMP & 3 & $3 \%$ \\
4 & High School & 30 & $30 \%$ \\
5 & D3 & 15 & $15 \%$ \\
6 & S1 & 30 & $30 \%$ \\
7 & S2 & 16 & $16 \%$ \\
8 & S3 & 6 & $6 \%$ \\
\hline \multicolumn{2}{c}{ Total } & $\mathbf{1 0 0}$ & $\mathbf{1 0 0 \%}$ \\
\hline
\end{tabular}

Based on Table 7 is very obvious that all sub officials who researched last education are high school level upwards.

Table 8 Characteristics of Respondents by Job

\begin{tabular}{clrr}
\hline No. & Work & Total & Percentage \\
\hline 1 & Military / Police & 5 & $5 \%$ \\
2 & PNS & 13 & $13 \%$ \\
3 & BUMN employee & 2 & $2 \%$ \\
4 & Private & 24 & $24 \%$ \\
5 & Entrepreneur & 27 & $27 \%$ \\
6 & More & 29 & $29 \%$ \\
\hline \multicolumn{2}{r}{ Total } & $\mathbf{1 0 0}$ & $\mathbf{1 0 0 \%}$ \\
\hline
\end{tabular}

Based on Table 8 above can be seen that the donors studied more work outside of government agencies. This is because usually, people who work in government agencies have been conditioned by BAZNAS, working with government agencies.

\section{b. Overview Variable}


Table 9

Respondents Variable Quality of Service

\begin{tabular}{lcrl}
\hline \multicolumn{1}{c}{ Indicator } & Item & Mean Score & Category \\
\hline Direct evidence (tangible) & $1-2$ & 4,29 & Very high \\
Reliability (reliability) & $3-5$ & 4,30 & Very high \\
Responsiveness (responsiveness) & $6-7$ & 4,39 & Very high \\
Guarantee (assurance) & $8-9$ & 4,28 & Very high \\
Empathy (empathy) & 10 & 4,4 & Very high \\
Shariah compliance (sharia & $11-12$ & 4,45 & Very high \\
compliance) & & &
\end{tabular}

Judging from Table 9, Synergy Foundation service quality is in the very high category. This means that the services performed by the Synergy Foundation to donors are much as expected by the donors. However, the quality of service of the highest of the sharia compliance level with an average value of 4,45. This is because the Synergy Foundation is an institution based on Islamic values, so that the Sharia compliance level of this institution would be kept.

Table 10

Summary of Respondents Variable Donor Trust

\begin{tabular}{lcrl}
\hline \multicolumn{1}{c}{ Indicator } & Item & Mean Score & Category \\
\hline Credibility & $13-15$ & 4,33 & Very high \\
Competence & $16-17$ & 4,3 & Very high \\
Moral Attitude & 18 & 4,52 & Very high \\
\hline Average & & $\mathbf{4 , 5 5}$ & \\
\hline
\end{tabular}

They viewed from Table 10, Synergy Foundation donor confidence in the very high category where trust donors highest of the moral attitude shown by the Synergy Foundation with an average value of variable donor trust is 4,55 .

Table 11

Summary of Respondents Variable of Donor Loyalty

\begin{tabular}{lrrc}
\hline \multicolumn{1}{c}{ Indicator } & Item & Mean Score & Category \\
\hline Routines donating (Repeat Purchase) & 19 & 4,17 & High \\
Faithful to the institution (Retention) & 20 & 3,97 & High \\
Recommend institution (referrals) & 21 & 3,56 & High \\
\hline The average variable Z & & $\mathbf{3 . 9}$ & \\
\hline
\end{tabular}

Referred from Table 11, Synergy Foundation donor loyalty is in the high category. However, loyalty is highest on their routines donate at Synergy Foundation with an average value of 4,17. This is because they are still routinely transacted in the Synergy Foundation over the last five years.

1) Testing Sub-structure 1: Effect of Quality Service (X) Against Belief (Y)

Table 12

Analysis Model Sub-structure 1- 1

\begin{tabular}{lrrrr}
\hline \multicolumn{1}{c}{ Variables } & Coefficient & Std. Error & $\begin{array}{c}\text { Standard } \\
\text { Coefficient }\end{array}$ & \multicolumn{1}{c}{ Probability } \\
\hline C & -0.111 & 1.526 & & .942 \\
Quality of service (X) & 0.469 & 0,037 & 0.791 & 0,000 \\
\hline Source: Data Processing & & & &
\end{tabular}

Based on the data processing in Table 12, it can be formed a regression equation with a mathematical model as follows:

$$
Y=-0.111+0,469 X+e
$$

From the regression equation above can be seen that:

1. The constant of 0.111 states that when the variable quality of service $(\mathrm{X})$ is equal to 0 , then the 
confidence of donors to the charity institution (Y) equal to 0.111

2. The regression coefficient on the variable quality of service (X) effect of 0.469 . This means that when the quality of service $(\mathrm{X})$ is increased by one unit, confidence in the zakat $(\mathrm{Y})$ institution increased by 0.469 .

From Table 12 to note also the path coefficient $\mathrm{X}$ to $\mathrm{Y}$ for $\mathrm{PYX}=0.942$

Next, will be discussed on the level of influence in the model are analyzed. The coefficient of determination using SPSS. Here are the results of the coefficient $\left(\mathrm{R}^{2}\right)$ in this study, as follows:

Table 13

The Coefficient of Determination $\left(\mathbf{R}^{2}\right)$

\begin{tabular}{ccrrr}
\hline Model & R & R Square & $\begin{array}{c}\text { Adjusted R } \\
\text { Square }\end{array}$ & $\begin{array}{c}\text { Std. Error of the } \\
\text { Estimate }\end{array}$ \\
\hline 1 & $0,791 \mathrm{a}$ & 0.626 & 0.623 & 2.68013 \\
\hline
\end{tabular}

Source: Data Processing (2018)

According to Table 13, the unknown coefficient of determination $\left(\mathrm{R}^{2}\right)$ of 0.626 . This means that in this study, the model of service quality variable (X) effect on the confidence of donors (Y) amounted to 62.6\%, and the remaining $37.4 \%$ is influenced by other variables that are not described in this study. So it can be made familiar sub-structure track 1 , which can be seen in the figure below.

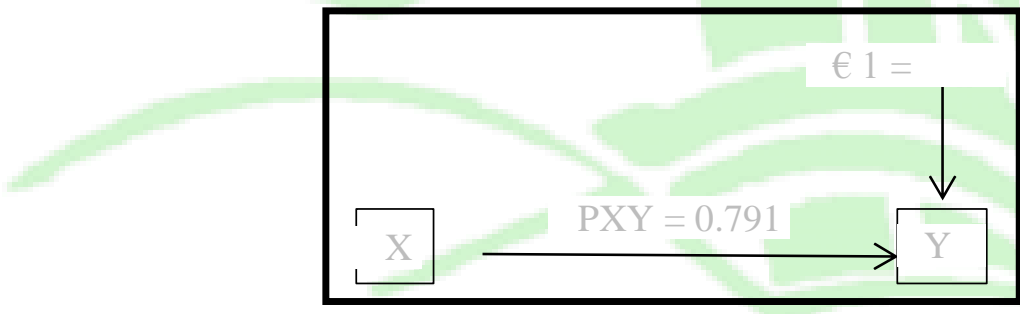

Figure 1

Path Analysis Model Diagram 1 The substructure 1

The results of hypothesis testing data in this study can be seen as follows:

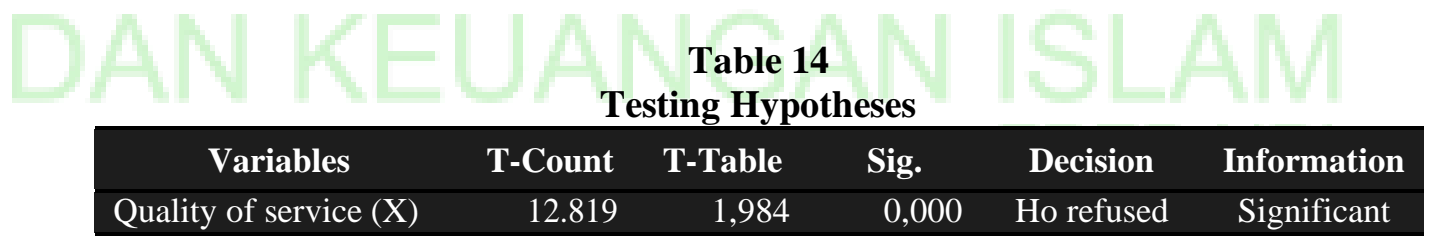

Source: Data Processing Results (2018)

Based on Table 14 above, the variable quality of service to donors' trust to the institution of zakat (Y) with a value of $12.819 \mathrm{t}>\mathrm{t}$ table amounted to 1.984 .0 .000 significance value $<0.05$, then Ho is rejected, and $\mathrm{Ha}$ is accepted. This means that the service quality variable path coefficient $(\mathrm{X})$ to the donor confidence variable $(\mathrm{Y})$ can be expressed as significant. So it can be concluded that the variable quality of service $(\mathrm{X})$ significantly affects the donor trust variable $(\mathrm{Y})$.

In empirical concept, this study is consistent with research conducted by Elrado et al. (2014) explained that the Quality of Service consists of five indicators of physical evidence (tangible), reliability, responsiveness, assurance, and empathy a significant effect on confidence. With a contribution of $43 \%$, the path coefficient $(\beta)$ of 0.419 , and the probability of $0.000(\mathrm{p}<0.05)$.

2) Testing Sub-structure 2: Effect of Quality of Service (X) and Trust (Y) to the Donor Loyalty (Z)

Table 15

Analysis Model 1-Sub-structure 2

Variables Coefficient Std. Error Standard Probability




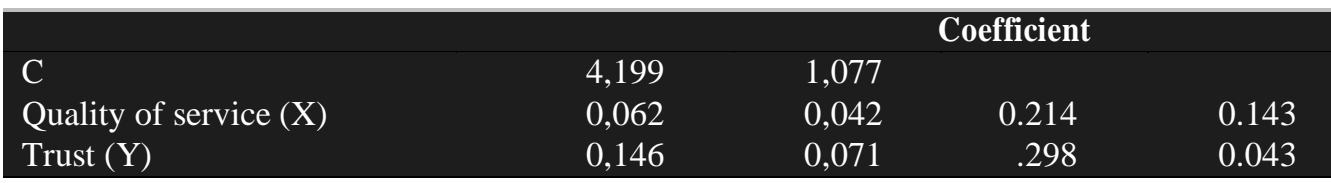

Source: Data Processing Results (2018)

Based on the data processing at Table 15, it can be formed a regression equation with a mathematical model as follows:

$$
Z=4,199+0,062 X+0,146 Y+e
$$

From the regression equation above can be seen that:

1. Constants of 4,199 declared when the variable quality of service (X) and trust (Y) equal to 0 , then the loyalty of donors $(\mathrm{Z})$ of 4,199 .

2. The regression coefficient on the variable quality of service $(X)$ effect amounted to 0,062 . This means that when the quality of service $(\mathrm{X})$ is increased by one unit, then the loyalty of donors (Z) of 0,062 .

3. The regression coefficient on the variable trust $(Y)$ effect of 0,146 . This means that when the trust of donors $(\mathrm{Y})$ is increased by one unit, donors' loyalty $(\mathrm{Z})$ is 0,146 .

From Table 15 to note also the path coefficients $\mathrm{X}$ to $\mathrm{Z}$ of $\mathrm{PXZ}=0.214$ and $\mathrm{Y}$ to $\mathrm{Z}$ of $\mathrm{PYZ}=$ 0.298. Next, will be discussed on the level of influence in the model are analyzed. The coefficient of determination using SPSS. Here the coefficient of determination (R2) in this study, as follows:

Table 16

The Coefficient of Determination $\left(\mathbf{R}^{2}\right)$

\begin{tabular}{|ccrrr} 
Model & $\mathbf{R}$ & R Square & $\begin{array}{c}\text { Adjusted R } \\
\text { Square }\end{array}$ & $\begin{array}{c}\text { Std. Error of the } \\
\text { Estimate }\end{array}$ \\
\hline 1 & $0,486 \mathrm{a}$ & 0.236 & .220 & 1.89131 \\
\hline Source: Data Processing Results (2018) & & \\
\hline
\end{tabular}

According to Table 16, the unknown coefficient of determination $\left(\mathrm{R}^{2}\right)$ of 0.207 . This means that in this study, the model of service quality variables $(\mathrm{X})$ and the confidence of donors $(\mathrm{Y})$ affect donor loyalty by $23,6 \%$, and the remaining $76,4 \%$ is influenced by other variables that are not described in this study. So it can be made standard sub-structure lines two, which can be seen in the following picture:

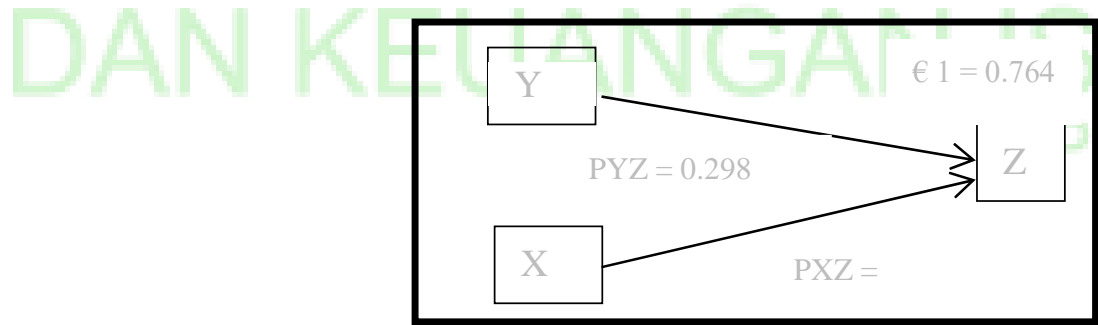

Figure 2

Path Analysis Diagram 1 Sub-structure Model 2

F test was used in this study to determine the influence of all exogenous variables on endogenous variables. Here are the results of the $\mathrm{F}$ test in this study with the following results:

Table 17

Significance Model (Test F)

\begin{tabular}{ccccc|}
\hline F-count & F-table & Sig. & Decision & Information \\
14.976 & 3.94 & 0,000 & receive Ha & Significant \\
\hline
\end{tabular}

In concept empirically that this study is consistent with the results of the research also proved by Agustiono and Sumarno (2006) in his research states that the higher quality of services provided and 
the confidence of consumers who use the product, the customer loyalty will be easier to set up. Kheng et al. (2010) also found that the quality of service and customer confidence strongly influence customer loyalty.

Table 18

Hypothesis Testing (t-Test)

\begin{tabular}{lccccc}
\multicolumn{1}{c}{ Variables } & t-Count & t-Table & Sig. & Decision & Information \\
$\begin{array}{l}\text { Quality of service } \\
\text { (X) }\end{array}$ & 1,477 & 1,984 & 0.143 & receive Ho & Not significant \\
Trust (Y) & 2,052 & 1,984 & 0.043 & Ho refused & Significant \\
Source: Data Processing Results (2018) & & & \\
\end{tabular}

Based on Table 18 above that the variable quality of service $(\mathrm{X})$ to the donor loyalty variable $(\mathrm{Z})$ with a value of 1,477 $t$ of $t$ table of 1,984 and 0,143 significance value $>0.05$, then Ho is accepted and Ha rejected. This means that the path coefficient service quality variable $(X)$ to the donor loyalty variable (Z) can be declared insignificant. So it can be concluded that the variable quality of service (X) does not affect the donor loyalty variable $(\mathrm{Z})$.

Theoretically, that according to Polyorat and Sophonsiri (2010), which has identified the quality of service as a determinant of customer loyalty suggests that "the higher the quality of services provided, the more likely customers will be loyal to the company. If customers feel it is understandable because the company provides good services, then consumers will re-use the product or service ". In contrast to the theory, the quality of service in a high-Synergy Foundation will not affect donor loyalty. Thereby indicating also that the improvement in the quality of service does not directly influence the increased donor loyalty but need improvement in donor confidence variable in several ways, among others, to maintain the trust of donors in the institution by always acting honestly, ensure that the institutions will always be relied upon by the donors, institutions have competence in carrying out their mandate, accountable to donors and is always open in conveying information to the donors. So expect to do so will be able to increase the loyalty of donors in the Synergy Foundation.

According to Table 18 above, the trust variable (Y) to the loyalty of donors (Z) with a value of 2,052 of $t$ table of 1,984 . The significance value of $0.043<0.05$, then Ho is rejected, and Ha accepted. This means the trust path coefficient $(\mathrm{Y})$ to variable donor loyalty $(\mathrm{Z})$ can be expressed significantly. So it can be concluded that the trust variable (Y) affects variable donor loyalty.

Empirically, this research was also supported by research by Elrado et al. (2014) that the variable trust consisting of two indicators of perceived competence and perceived fairness shown to have a significant effect on loyalty. With a contribution of $64.9 \%$, the path coefficient $(\beta)$ of 0.162 , and a probability of $0.031(\mathrm{p}<0.05)$.

\section{3) Testing Sub-structure 2: Effect of Donor Trust $(X)$ to the Donor Loyalty $(Z)$ after Trimming}

Trimming the model is a model that is used to fix a model structure by removing the path analysis of models of exogenous variables that were not significant path coefficients (Ridwan \& Kuncoro, 2012). Path analysis model 2 sub-structure two is used to determine the effect of donor confidence (Y) on the loyalty of donors $(\mathrm{Z})$. The acquisition of the results of sub-structure model $2 \mathrm{t}$ is as follows:

Table 19

Analysis Model 2-Substructure 2

\begin{tabular}{lrrrrr} 
Variables & Coefficient & Std. Error & $\begin{array}{l}\text { Standard } \\
\text { Coefficient }\end{array}$ & Probability \\
C & 5.165 & .860 & & 0.468 & 0,000 \\
Donors trust & .230 & 0,044 & & 0,000 \\
& & & & \\
\hline
\end{tabular}

Based on the data processing in Table 19, it can be formed a regression equation with a mathematical model as follows:

$$
Z=5.165+0,230 X+e
$$


From the regression equation can be seen that:

1. The constant of 5.165 states that when the donor confidence variable (Y) is equal to 0 , the loyalty of donors $(\mathrm{Z})$ is 5.165 .

2. The regression coefficient on variable donor trust $(Y)$ effect of 0.230 . This means that the confidence of donors $(\mathrm{Y})$ is increased by one unit, then the loyalty of donors $(\mathrm{Z})$ of 0.230 .

Next, will be discussed on the level of influence in the model are analyzed. The coefficient of determination using SPSS. Here the coefficient of determination $\left(\mathrm{R}^{2}\right)$ in this study, as follows:

Table 20

The Coefficient of Determination $\left(\mathbf{R}^{2}\right)$

\begin{tabular}{|crrrr} 
Model & R & R Square & $\begin{array}{c}\text { Adjusted R } \\
\text { Square }\end{array}$ & $\begin{array}{c}\text { Std. Error of the } \\
\text { Estimate }\end{array}$ \\
\hline 1 & $0,468 \mathrm{a}$ & .219 & 0,211 & 1.90268 \\
\hline Source: Data Processing Results $(2018)$ & & \\
\end{tabular}

According to Table 20 unknown coefficient of determination $\left(\mathrm{R}^{2}\right)$ of 0,219 . This means that in this study, the variables of trust donors $(\mathrm{Y})$ to the loyalty of donors $(\mathrm{Z})$ by $21,9 \%$ and the remaining $78,1 \%$ is influenced by variables other parties that are not described in this study. So it can be made standard sub-structure lines 2 , which can be seen in the following picture:

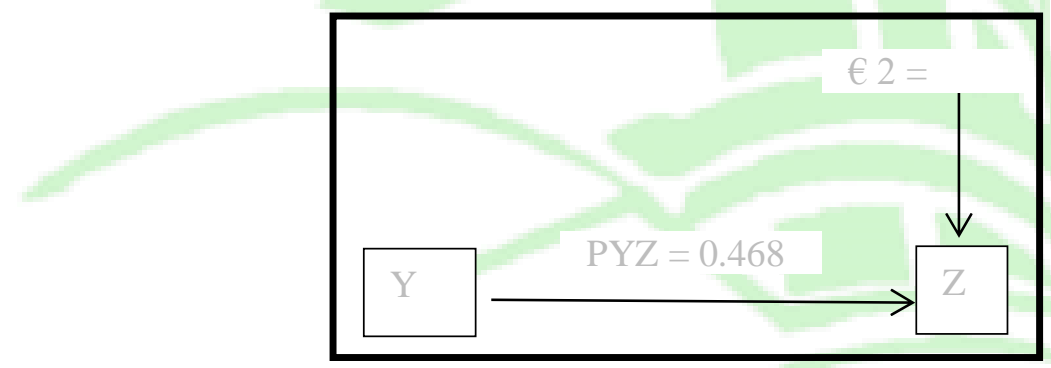

Figure 3

Diagram Path Analysis Model 2 Sub-Structure 2

The T-test used in this study is to determine the effect of exogenous variables on endogenous variables.

Here's the T-test result in this study. With the following results:

Table 21

Hypothesis Testing (t-test)

\begin{tabular}{cccccc}
\hline Variables & $\mathbf{t}$-Count & t-Table & Sig. & Decision & Information \\
trust donors (Y) & 5.238 & 1,984 & 0,000 & Ho refused & Significant \\
\hline
\end{tabular}

Source: Data Processing Results (2018)

According to Table 21 above, the donor confidence variable $(Y)$ to the loyalty of donors $(\mathrm{Z})$ with a value of 5,238 $t$ count $>t$ table amounted to 1,984. 0,000 significance value $<0.05$, then Ho is rejected, and $\mathrm{Ha}$ is accepted. This means that the path coefficient donor trust variables (Y) to donors' loyalty $(\mathrm{Z})$ can be expressed significantly. So it can be concluded that the donor confidence variable (Y) significantly affects the loyalty of donors variables (Z).

Empirically, this research is also supported by previous studies such as by Elrado, et al. (2014) that the variables of trust shown to have a significant influence on loyalty with a contribution of $64,9 \%$, the path coefficient $(\beta)$ of 0,162 , and a probability of $0,031(\mathrm{p}<0.05)$.

4) Effect of Quality of Service (X) to the Donor Loyalty (Z) with Donor Trust as an Intervening Variable (Y) 
Effect of intervening or intermediary to determine if there is a significant or not through an intervening variable or intermediary. Variable quality of service to the loyalty of donors and donor confidence as an intervening variable in the test using the Sobel test (Ghozali, 2013) as follows:

Based on the results, we can calculate the statistical value of the effect of mediation with the following formula:

$$
\begin{aligned}
& \mathrm{t}=\frac{p 2 p 3}{S p 2 p 3} \\
& =\frac{0,219492}{0,02238113} \\
& =9,807011532 \text { (Rounded to } 9,807)
\end{aligned}
$$

Therefore $t$ value of 9,807 is more significant than the $t$ table with a significance level of 0,05 is equal to 1,984 . It can be concluded that the coefficient is significant mediation which means there is the influence of intervening.

Decomposition of influence between the variables used to determine the effect of each variable's direct and indirect effect in our model. The following table decomposition of influence between variables in this study are:

Table 22

Decomposition Effect Among Variables

\begin{tabular}{lrrr}
\multicolumn{1}{c}{$\begin{array}{c}\text { Between the Influence of } \\
\text { Variables }\end{array}$} & \multicolumn{2}{c}{ influence of Causal } & \multirow{2}{*}{ Total } \\
X to Y & 0,791 & Indirect (via Y) & 0,791 \\
X to the Z &, $298 \quad(0.298 \times 0.468)=0.134$ & 0,432 \\
Y to Z & 0,468 & & 0,468 \\
Source: Data processing results (2018) & \multicolumn{3}{l}{}
\end{tabular}

Based on the overall calculation results in Table 22, then the information can be obtained as follows: The research hypothesis sub-structure model of equation one can be explained by the results of the calculation with an explanation stating that the interpretation of the data, the path coefficient $\mathrm{X}$ to $\mathrm{Y}$ with the quality of service affect the confidence of donors to direct zakat institution acceptable to the influence of 0,791 or $79,1 \%$.

The calculation results can explain the research hypothesis sub-structure model of equation 2 with an explanation stating that the interpretation of the data, the path coefficients $\mathrm{X}$ to $\mathrm{Z}$ with the hypothesis does not affect service quality directly affects the loyalty of donors. Therefore, the effect of indirectly or through Y can be accepted with effect totaled 0,432 or $43,2 \%$. Then the path coefficient $\mathrm{Y}$ to $\mathrm{Z}$ with the confidence of donors to the charity institutions affect the loyalty of donors can immediately be accepted by the effect of 0,468 or $46,8 \%$. So the models that succeed in this path analysis method that the pictures are shown as follows:

\section{CLOSING}

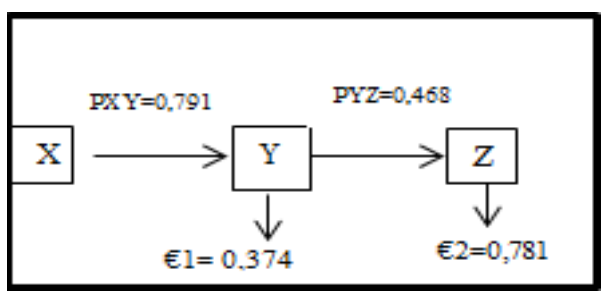


Based on the results of research and discussion of the previous chapter, we can conclude that first, the Synergy Foundation has a quality of service and a very high level of confidence. This means that donors are very satisfied with the service Synergy Foundation. Then loyalty to the Synergy Foundation donors is in a high category. Second, the quality of service is a significant effect on the confidence of donors. Third, the quality of service does not significantly influence the loyalty of donors to the Synergy Foundation. Third, donors' trust significant effect on donor loyalty to the Synergy Foundation. Fourth, the quality of service significantly influences donor loyalty through donor confidence as an intervening variable.

\section{Suggestion}

Consumer loyalty, in this case, is muzakki, and not only based on service satisfaction built by an institution but also built on trust. Therefore, it is essential if a company builds customer trust, in this case, is muzakki. Muzakki trust can be built through several conditions, including improving the attitude of amil that is friendly, responsive to donor complaints, punctuality in picking up donations, and empathy to donors.

\section{REFERENCE}

Agustianto. (2013, september 04). Multi Level Marketing Menurut Hukum Islam. Sistem Pemasaran MLM.

Agustino, \& Sumarno. (2006). Analisis Pengaruh Kualitas Pelayanan Jasa Terh.adap Kepercayaan dan Loyalitas Pasien Rawat Inap di Rumah Sakit ST. Elisabeth Semarang. Majalah Ilmiah Kopertis, $1(1), 1-18$.

Alghipari. (2013). Statistika Induktif. yogyakarta: UPP STIM YKPN.

Alma, B. (2008). Pengantar Bisnis Edisi Revisi. Bandung: Alfabeta.

Arikunto, S. (2013). Prosedur Penelitian: Suatu Pendekatan Praktik. Jakarta: Rineka Cipta.

Arsyianti, I. S. (2015). CONSTRUCTION OF CIBEST MODEL AS MEASUREMENT OF POVERTY AND WELFARE INDICES FROM ISLAMIC PERSPECTIVE. Jakarta: Jurnal Al-Iqtishad.

Aydin, N. (2017). Islamic versus conventional human development index: empirical evidence from ten Muslim countries. Los Angeles: Emerald Insight.

Azzuhra. (2016). BI targetkan transaksi Fintech capai 194,3 T. Jakarta: Merdeka.com.

Badan Amil Zakat Nasional. (2016). Zakat Community Development. Jakarta: pusat.baznas.go.id.

Badan Amil Zakat Nasional. (2018). Indonesia Zakat Outlook. jakarta: baznas.go.id.

BankIndonesia. (2016, july 28). Temu Ilmiah Regional Kemkoinfo-2016. Retrieved october 01, 2017, from from skim.kominfo.go.id: skim.kominfo.go.id/.../Bank\%20Indonesia\%20\%20Materi\%20Temu\%20Ilmiah.pdf

BPS. (2017, 01 03). Profil kemiskinan di indonesia 2016. Retrieved 07 18, 2017, from Badan Pusat Statistik: https://www.bps.go.id/Brs/view/id/1378

BPS. (2017). Profil kemiskinan di indonesia 2017.

Budiman, A. (2017). Titik Industri Baru di Jawa Barat Akan Bergairah. Jakarta: Pikiran Rakyat.

Bungin. (2011). Metodologi Penelitian Kuantitatif Komunikasi, Ekonomi, dan Kebijakan Publik Serta Ilmu-ilmu Sosial Lainnya. Jakarta: Kencana Prenada Media Group.

Chrismastianto, I. A. (2017 ). Analisis Swot Implementasi Teknologi Finansial Terhadap Kualitas Layanan Perbankan Di Indonesia . Jurnal Ekonomi dan Bisnis, Volume 20 No. 1.

Ciptono, F. (2011). Pemasaran Jasa. Yogyakarta: Bayumedia Publishing. 
Darwin, \& Kunto. (2014). Analisis Pengaruh Kualitas Pelayanan terhadap Loyalitas Pelanggan dengan Kepuasan dan Kepercayaan sebagai Variabel Intervening pada Asuransi Jiwa Manulife Indonesia-Surabaya . Jurnal Manajemen Pemasaran Petra Vol. 2, No. 1, 1-12.

Dewi, N. (2017). REGULASI KEBERADAAN BAITUL MAAL WAT TAMWIL (BMT). Serambi Hukum.

Dian Komala Sari, D. H. (2014). ANALISIS PENDAPATAN DAN TINGKAT KESEJAHTERAAN RUMAH TANGGA PETANI JAGUNG DI KECAMATAN NATAR KABUPATEN LAMPUNG SELATAN. Jakarta: JIIA, VOLUME 2, No. 1.

Eka Pratiwi Lumbantoruan, P. H. (2016). ANALISIS PERTUMBUHAN EKONOMI DAN INDEKS PEMBANGUNAN MANUSIA (IPM) PROVINSI-PROVINSI DI INDONESIA (METODE KOINTEGRASI). Jakarta: Jurnal Ekonomi dan Keuangan Vol.2 No.2.

Elrado, M., Kumadji, S., \& Yulianto, E. (2014). PENGARUH KUALITAS PELAYANAN TERHADAP KEPUASAN, KEPERCAYAAN DAN LOYALITAS. Jurnal Administrasi Bisnis (JAB)|Vol. 15 No. 2, 2.

Fatmawati. (2015). Jurnal Iqra Vol 09. Jurnal Iqra Vol 09.

Fatmawati. (2015). Jurnal Iqra Vol 09. Retrieved October 02, 2017, from download.portalgaruda.org: download.portalgaruda.org/article.php?...TECHNOLOGY\%20ACCEPTANCE\%20M...

Fauzi, H. (2013). pengertian pembangunan . Retrieved july 18, 2017, from digilib.unila.ac.id: digilib.unila.ac.id/982/8/BAB\%20II.pdf

Ferdinad, A. (2014). Metode Penelitian Manajemen. Semarang: Universitas Diponegoro.

Firdaus, M., \& Beiq, I. S. (2012). Economic Estimation and Determinations of Zakat Potential in Indonesia. Working Paper Series WP\#1433-07 (pp. 1-30). Jeddah: Islamic Research and Training Institute.

Ghozali, I. (2006). Aplikasi Analisis Multivariate dengan Program SPSS. Semarang: Badan Penerbit UNDIP.

Ginting, I. I. (2015). ANALISIS STRATEGI PENGEMBANGAN BMT (BAITUL MAAL WAT. Jurnal Ekonomi dan Keuangan.

Gunawan. (2017). Pelayanan Lembaga Zakat untuk Meningkatkan Kepuasan Muzakki . Jurnal Ziswaf Vol. 4 No. 2, 297-312.

Hasrina, C. D., Yusri, \& Agusti , D. (2018). Pengaruh Akuntabilitas dan Transparansi Lembaga Zakat Terhadap Tingkat Kepercayaan Muzakki dalam Membayar Zakat di Baitul Mal Kota Banda Aceh. Jurnal Humaniora, Vol. 2, No. 1, 1-9.

Indonesia, B. (2016, july 28). Temu Ilmiah Nasional Peneliti 2016 -Kemkominfo. Retrieved july 18, 2017, from skim.kominfo.go.id: skim.kominfo.go.id/.../Bank\%20Indonesia\%20\%20Materi\%20Temu\%20Ilmiah.pdf

Irfan Syauqi Beik, L. D. (2015). Construction of CIBEST Model as Measurement of Poverty and Welfare Indices From Islamic Perspective. Al-Iqtishad: Vol. VII No. 1, 93.

irham, d. A. (2014). ANALISIS KESESUAIAN SYARIAH PADA SISTEM OPERASI BISNIS MULTI LEVEL MARKETING (MLM). JESST VOL 1, 04.

Jasfar, F. (2012). Manajemen Jasa, Pendekatan Terpadu. Jakarta: Ghalia Indonesia.

Juariyah, B. d. (2010). ANALISIS KONDISI SOSIAL EKONOMI DAN TINGKAT PENDIDIKAN MASYARAKAT DESA SRIGADING, KECAMATAN LABUHAN MARINGGAI, KABUPATEN

LAMPUNG TIMUR. Jurnal Ekonomi \& Pendidikan, Volume 7 Nomor 1.

Kadji, Y. (2013). Kemiskinan dan konsep teoritisnya. Respository UNG, 1. 
Kasriyati. (2012). Kemiskinan dan kebijakan pengentasannya. Retrieved july 18, 2017, from www.kulonprogokab.go.id: www.kulonprogokab.go.id/v21/files/Kemiskinan-dan-KebijakanPengentasannya.pdf

Kheng, Mahamad, O., \& Ramayah, T. (2010). The Impact of Service Quality on Customer Loyalty: A Study of Banks in Penang, Malaysia. International Journal of Marketing Studies, 2(2): 57-66.

Kotler, \& Keller. (2009). Manajemen Pemasaran Edisi Ke 13. Jakarta: Erlangga.

Kunjojo. (2009). Metodologi Penelitian. Kediri: Tidak diterbitkan.

Lubis, D. (2018). MENGUKUR KINERJA PENGELOLAAN ZAKAT DI BADAN AMIL ZAKAT NASIONAL (BAZNAS). Bogor: journal.febi.uinib.ac.id.

Lusiati. (2010). Pengaruh Kualitas Pelayanan terhadap Kepuasan dan Loyalitas Muzakki Lembaga Amil Zakat Dana Sosial Nurul Islam Amanah Batam. TESIS, 1-100.

Maisur; Arfan, Muhammad; Shabri;. (2015). PENGARUH PRINSIP BAGI HASIL,TINGKAT PENDAPATAN, RELIGIUSITAS DAN KUALITAS PELAYANAN TERHADAP KEPUTUSAN MENABUNG NASABAH PADA BANK SYARIAH DI BANDA ACEH. Jurnal Magister Akuntansi Volume 4, No. 2, Mei, 1-8.

Masyithoh, N. D. (2014). Analisis Normatif Undang-Undang No. 1 Tahun 2013 Tentang Lembaga Keuangan Mikro (Lkm) Atas Status Badan Hukum Dan Pengawasan Baitul Maal Wat Tamwil (Bmt). Volume V/Edisi 2.

Moh. Siri1, F. A. (2017). Analisis Sikap Pengguna Paytren Menggunakan Technology Acceptance Model. jurnal informatika, 265.

Moleong. (2012). Metodologi Penelitian Kualitatif. Bandung: Pt Remaja Rosdakarya.

Moleong, L. J. (2002). Metodologi penelitian kualitatif. Bandung: Remaja Karya.

Morissan. (2012). Metode Penelitian Survei. Jakarta: Prenadamedia Group.

MUI, D. (2017, februari). DSN MUI-FATWA. Retrieved july 23, 2017, from dsnmui.or.id: dsnmui.or.id/page $/ 59 /$ mact=News $\% 2 \mathrm{Cm} 0 \mathrm{f} 80 \mathrm{~d} \% 2 \mathrm{Cdefault} \% 2 \mathrm{C} 1 \& \mathrm{~m} 0 \mathrm{f} 80 \mathrm{dcateg}$ ory=Fatwa\& m0f80dnumber $=20 \& \mathrm{~m} 0 \mathrm{f} 80 \mathrm{ddetailpage}=61 \& \mathrm{~m} 0 \mathrm{f} 80 \mathrm{ddetailtemplate}=$ Fatwa $\& \mathrm{~m} 0 \mathrm{f} 80 \mathrm{dpagenumb}$ er $=2 \&$ m0f80dreturnid $=59$

Mutaqqin, A. ( 2012 ). MODEL PEMBIAYAAN BAITUL MAAL WA TAMWIL DAN PERANANNYA DALAM PEMBINAAN KESEJAHTERAAN USAHA KECIL MENENGAH (UKM). JURNAL HUMANITY Volume 7, Nomor 2.

Narendran, N. M. (2016). The human development index predicts female entrepreneurship rates. Los Angeles: Emerald Insight.

Nasim, A., \& Romdhon, S. M. (2014). PENGARUH TRANSPARANSI LAPORAN KEUANGAN, PENGELOLAAN ZAKAT, DAN SIKAP PENGELOLA TERHADAP TINGKAT KEPERCAYAAN MUZAKKI (Studi Kasus Pada Lembaga Amil Zakat Di Kota Bandung). JURNAL RISET AKUNTANSI DAN KEUANGAN, 2 (3), 550-561.

Nasution, R. (2003). populasi dan sampel. Retrieved november 02, 2017, from library.usu.ac.id: library.usu.ac.id/download/fkm/fkm-rozaini.pdf

Nazir, M. (1998). Metode Penelitian. Jakarta: Ghalia Indonesia.

Nuraini, \& Ridho. (2015). Pengaruh Kualitas Pelayanan, Citra Lembaga dan Religiusitas terhadap Minat Muzakki untuk Menyalurkan Zakat Profesi (Studi di Pos Keadilan Peduli Ummat Yoyakarta). Jurnal MD, 207-228.

Nuryahya, E. (2017). Optimization Financial Technology Through the Application of E-Money Paytren : Reduce Poverty in Indonesia As a Direct Marketing Syariah Tiered (plbs). 
Pemerintah. (2008). Undang Undang Republik Indonesia nomor 21 tahun 2008. Jakarta: Negara.

Pemerintah Desa Cipancar. (2018). Profil desa cipancar. Subang: Pemerintah Desa Cipancar.

Polyorat, K., \& Sophonsiri, S. (2010). Pengaruh Hubungan Kualitas Layanan, Kepuasan dan Loyalitas. Journal of Global Business and Technology, 2.

Pusat Kajian BAZNAS. (2017). Indeks Desa Zakat. jakarta: puskabaznas.

Puskabaznas. (2017). Indeks Desa Zakat. Jakarta: Puskabaznas.go.id.

Qomariah. (2012). Pengaruh Kualitas Pelayanan dan Citra Institusi terhadap Kepuasan dan Loyalitas Konsumen . Jurnal Aplikasi Manajemen Vol. 10, No. 1, 177-187.

Rahman, R. A. (2012, 06 13). Challenges and solutions in Islamic microfinance. Humanomics . Retrieved 01 02, 2018, from www.emeraldinsight.com/: http://www.emeraldinsight.com/ doi/full/

Ramani, A. (2014). HUBUNGAN INDEKS PEMBANGUNAN MANUSIA DENGAN INDIKATOR PENYAKIT, LINGKUNGAN, DAN GIZI MASYARAKAT (Analisis Data Sekunder Negara Anggota UNDP). Jakarta: Jurnal IKESMA Volume 10 Nomor 1.

repository. (2013). kemiskinan. Retrieved ocotober 01, 2017, from repository.usu.ac.id.

Ridwan, \& Kuncoro. (2012). Cara Menggunakan Dan Memaknai Path Analysis (Analisis Jalur). Bandung: Alfabeta.

Riyanto, J. (2017). IMPLIKASI PENGGUNAAN DANA DESA TERHADAP KETAHANAN SOSIAL, EKONOMI, DAN EKOLOGI DESA TERTINGGAL DI KABUPATEN KARANGANYAR. Surakarta: Jurnal SAINSTECH Politeknik Indonusa Surakarta.

Rosni. (2017). ANALISIS TINGKAT KESEJAHTERAAN MASYARAKAT NELAYAN DI DESA DAHARI SELEBAR KECAMATAN TALAWI KABUPATEN BATUBARA. Jakarta: Jurnal Geografi eISSN: 2549-7057 | p-ISSN: 2085-8167.

Saifulloh, N. I. (2017). ANALISIS TINGKAT KEMISKINAN KAUM URBAN BERDASARKAN INDEKS CIBEST DI KECAMATAN KEPIL KABUPATEN WONOSOBO. Purwokerto: Jurnal IAIN Purwokerto.

Saktiandy, D. E. (2013). Pengaruh Program Pemberdayaan dan Kualitas Pelayanan terhadap Kepuasan dan Loyalitas Pembayar ZIS dalam membayar Zakat, Infak dan Shodaqoh di LAZ yang berkantor pusat di Surabaya. TESIS, 1-170.

Salma, F. S. (2015). PENGARUH KUALITAS JASA PERSPEKTIF ISLAM TERHADAP KEPUASAN DAN LOYALITAS PELANGGAN HOTEL GRAND KALIMAS DI SURABAYA. JESTT Vol. 2 No. 4 April 2015, 322-339.

Setiawan, S. (2017, Februari 13). Guru Pendidikan. Retrieved from Studi Kepustakaan" Pengertian \& ( Tujuan, Peranan, Sumber, Strategi): http://www.gurupendidikan.co.id/studi-kepustakaanpengertian-tujuan-peranan-sumber-strategi/

Setyobakti, M. h. (2017). IDENTIFIKASI MASALAH DAN POTENSI DESA BERBASIS INDEK DESA MEMBANGUN (IDM) DI DESA GONDOWANGI KECAMATAN WAGIR KABUPATEN MALANG. Jakarta: Jurnal Penelitian Ilmu Ekonomi WIGA Vol. 7.

siregar, M. E. (2016, september 27). September 2016, pangsa pasar bank syariah tembus 5,3\%. Retrieved july 2017, 23, from finansial.bisnis.com: http://finansial.bisnis.com/read/20160927/90/587449/september-2016-pangsa-pasar-banksyariah-tembus-53

Solihin, A. I. (2011). Mencermati Bisnis Penjualan Langsung Berjenjang Syariah (MLM Syariah). jakarta: kompasiana.com. 
Sugiyarto. (2015). KEMISKINAN DAN KETIMPANGAN PENDAPATAN RUMAH TANGGA. Agro Ekonomi.

Sugiyati, K. (2013). Pengaruh Kualitas Pelayanan Jasa dan Kepercayaan Terhadap Loyalitas Pelanggan dengan Kepuasan Pelanggan Sebagai Variabel Intervening. Dinamika Manajemen Vol. 3 No. 2 , 113-128.

Sugiyono. (2009). Metode Penelitian Bisnis. Bandung: Alfabeta.

Sugiyono. (2010). Metode Penelitian Kuantitatif, Kualitatif dan R\&D,. bandung: Alfabeta.

Sulaeman, E. S. (2010). Model Pemberdayaan Masyarakat Bidang Kesehatan, Studi Program Desa Siaga. Artikel Penelitian.

Sumantri, R. (2017). EFEKTIFITAS DANA ZAKAT PADA MUSTAHIK ZAKAT COMMUNITY

DEVELOPMENT SUMATERA SELATAN DENGAN PENDEKATAN CIBEST. Jakarta: IEconomic Vol.3. No 2.

Sunyoto, D. (2013). Metode Penelitian Akuntansi. Bandung: Pt. Rafika Aditama Anggota Ikapi.

Sutomo, Najib, M., \& Djohar, S. (2017). PENGARUH KUALITAS PELAYANAN LEMBAGA AMIL ZAKAT (LAZ) TERHADAP KEPUASAN DAN LOYALITAS MUZAKKI (STUDI KASUS LAZ PKPU YOGYAKARTA). Jurnal Aplikasi Bisnis dan Manajemen, Vol. 3 No. 1, Januari 2017, 59-70.

Tempo. (2016). Penduduk Miskin Subang Capai 700 Ribu . Jakarta: nasional.tempo.co.

Tope, P. (2010). Analisis kinerja pembangunan ekonomi kabupaten parigi mautong. palu: media Litbang sulteng.

Treni. (2016). Paytren. Retrieved 07 19, 2017, from treni PT Veritra Sentosa Internasional: https://www.baru.treni.co.id

treni. (2017). company profile. Retrieved july 18, 2017, from www.treni.co.id: www.treni.co.id/aboutus/

Umar, H. (2014). Faktor-faktor yang Memengaruhi Loyalitas Pelanggan pada Penerbangan Low Cost Carrier. urnal Manajemen Transportasi \& Logistik (JMTransLog) - Vol. 01 No. 02,, 129.

Usria, F. (2014). Implementasi dan Peran CSR terhadap Kepercayaan Anggota BMT Fastabiq Pati. Iqtishodia Vol. 7 No. 2, September.

Wantara, P. (2015). The Relationships among Service Quality, Customer Satisfaction, and Customer Loyalty in Library Services. International Journal of Economics and Financial Issues, 2015, 5(Special Issue), 264-269.

Widodo, H. (1999). Panduan Praktis Operasional Baitul Maal wat Tamwil (BMT). Dompet Duafa Republika.

Wijaya, T. ( 2011). Manajemen Kualitas Jasa. Edisi 1. Jakarta: Indeks.

WorldBank. (2002). Menciptakan lapangan kerja. Retrieved july 18, 2017, from siteresources.worldbank.org: siteresources.worldbank.org/INTINDONESIA/Resources/.../creatingjob.pdf

Yazid, A. t. (2017). Faktor - Faktor Y ang Mempenagruhi Minat Muzakki Dalam Menunaikan Zakat di Nurul Hayat Cabang Jember. Jurnal Ekonomi dan Hukum Islam, Vol.8, No. 2 , 173-199.

Yusrizal, ghafur, A., \& Sabri, H. (2017). PENGARUH MARKETING SOSIAL DAN OPTIMISME AMIL ZAKAT TERHADAP OPTIMALISASI FUNDRAISING DANA ZAKAT. Islamic Economic Development (p. 321). Batusangkar: International Conference.

Zulfa, M. (2010). Pengaruh Kualitas Pelayanan Islami dan Citra Terhadap Kepuasan dan Loyalitas Pasien Rumah Sakit Islam Jawa Tengah. Disertasi 


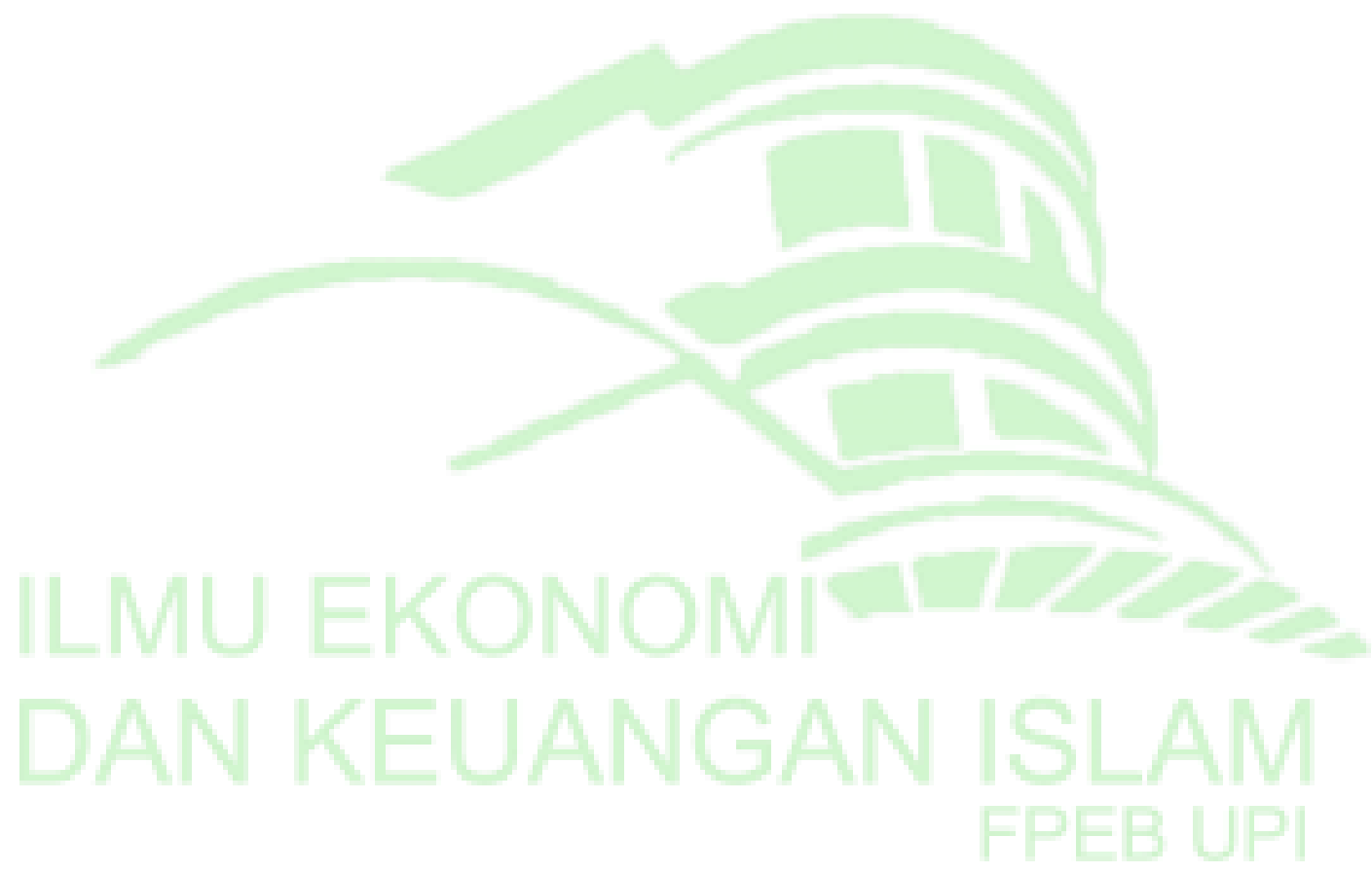

